\section{ON THE GENERA STREPTOTHRIX AND CLADOTHRIX OF COHN.}

By G. W. DAMMAN, M.B., Ch.B. MelB., ASSISTANT BACTERIOLOGIST TO PROFESSOR RAY LANKESTER, OXFORD UNIVERSITY.

WrTHIN the last year or two several observers on the Continent have isolated and described a species of micro-organism consisting of branched mycelium-like threads, and therefore not belonging to the Schizomycetes. So far as Iam aware no one has described anything similar in this country, and therefore I make a few remarks about these plants and bring before the readers of THE LANCET the results of my own observations. But before entering into general considera tions I shall first lescribe three members of this group which I have isolated and cultivated, one being chromogenic and the others colourless.

Streptothrix $\boldsymbol{A}$.

This organism was isolated on four occasions from un. filtered Thames water and closely resembles the oöspora Metchnikowi of Sauvageau and Radais; also a plant described by Macé, which he erroneously considers identical with Cladothrix dichotoma of Cohn.

Morphology. - The cultures are so firm and adherent that cover-glass preparations are difficult to make. Preparations show fine filaments, with branches ramifying in all directions. There is no regularity in the branches, which are more numerous in some filaments than in others, or in different parts of the same filament. They arise as a small lateral bud at right angles to the axial stem but may rapidly incline at an angle to the mother stem and become more or less wavy or curled. The threads vary somewhat in thickness; Sauvageau and Radais explain this as being due to two threads running side by side for some distance. This explains the appearance in some cases, but in others it is certainly due to difference in thickness of the filaments themselves. This is all that can be seen of their structure when stained by gentian violet or fuchsine, but if stained by methylene blue, or still better by Gram's method, it is at once seen that the filaments are not homogeneous; they are irregularly broken up into stained and unstained portions, so as to resemble short leptothrix forms, long and short rods, and coccus forms. This appearance is seen also in the fresh state and in cultures of all ages. This is undoubtedly what Cohn and Zopf have described as segmentation into micrococci, bacilli, leptothrix and spirilla. But they never become free, and in my opinion are due simply to an irregular distribution of the protoplasm, because $I$ have seen all stages of their formation, from scarcely perceptible granularity to the most perfect chains of bacilli.

Biology. - The organism appears on gelatine plates in two or three days as yellowish-white points, gradually increasing in size and forming a fairly prominent button-like colony with a matt surface and rounded outline. The gelatine surrounding the colony assumes a brown colour to the extent of about two millimetres, afterwards darkening almost to black. Under the microscope the colony appears as a dark brown mass, opaque in the centre; the margins consist of a confused network of threads, which is rather looser at the periphery. In about a week it forms a brownish-white, tough, coherent skin, slightly sunken owing to liquefaction of the gelatine, and the skin can be removed en masse. In puncture cultivations there is a brownish-white growth on the surface, which may afterwards become somewhat wrinkled, but which never reaches the walls of the tube. Along the needle track there are a few indistinctly contoured colonies in the upper part, which with a lens are frequently seen to have a radial arrangement. The gelatine is stained brown, but the colour never extends to any depth in the gelatine. Liquefaction begins in about a week, but is slow and incomplete. On agar-agar it forms discrete brownish-white colonies, which also produce the dark discolouration of the medium to which the culture is very firmly adherent. The condensation fluid is stained brown. In nutrient bouillon kept in the incubator at $35^{\circ} \mathrm{C}$. it grows very slowly, forming isolated colonies which do not render the fluid cloudy. These colonies consist of small rounded flakes which collect at the bottom of the culture tube. When one of these flakes is transferred to a slide it is seen to consist of a dense mass of filaments, which can only be distinguished at the periphery. The whole fluid is stained a deep brown.
Cladothrix $B$.

This was also obtained from Thames water, and presents several marked differences from the preceding variety.

Morphology.-In gelatine cultures we see long filaments which may consist of two or more relatively shorter threads, and may show remarkable tortuosity. As preparations are more easily made than in the case of the preceding organism, the branches are very distinctly seen, and close observation shows that the branching is pseudo-dichotomous. The branches start as lateral buds, which are not necessarily at right angles to the parent stem and may exceed the latter in length. In many preparations a colourless sheath, about four times as wide as the protoplasmic portion, may be demonstrated, but it remains unaffected by any of the ordinary stains. As in Streptothrix A., methylene blue and Gram's stain show the so-called segmentation very distinctly But in agar and bouillon cultures, especially if young, the filaments consist of large sausage-shaped lacilli strung together and connected by a colourless sheath. The filaments are not of uniform width and the extremities may present club-shaped swellings. In some places the unstained portion of the filament is seen to be much wider than at others, and there may be a series of these swellings separated by intervening contractions which are deeply stained. The former I take to be simple dilatations of the sheath.

Biology.-The organism grows fairly rapidly in gelatine plate cultivations. Abont the fourth clay the plate is dotted with white, rounded, coherent colonies which have an uneven surface and under the microscope appear dark and opaque Two days later the margin is seen to consist of a meshwork of threads. In puncture cultivations a grey wrinkled layer is seen on the surface, which during the next few days becomes more flattened and sometimes shows concentric rings. There is luxuriant growth along the puncture in the form of a thick white streak. Liquefaction begins in five or six days and extends gradually downwards, the liquefied gelatine being turbid and opaque. On agar-agar there is rapic development of a broad grey shining band, the margins of which show transverse striation. Potato cultures are pecnliar. At first there is rapid and abundant derelopment of a shining. raised, colourless, sometimes opalescent growth, which in the course of a few days becomes covered with a pasty skin anc afterwards subsides to the bottom of the tube. Boullon remains clear; but a few fine flakes are deposited at the bottom, consisting of chains of large bacilli bent on eacb other at an angle.

\section{STREPTOTHRIX}

This organism was isolated from the saliva of a healthy individual. Its morphology is similar in every respect tc that of Streptothrix A, but in addition there are certain threads which correspond to Conidia ; they are usually short and thick and occasionally branched. The process of sport formation is this : The filament swells somewhat and becomes. slightly granular; the contour then becomes sinuous, and there is an appearance of segmentation into coccus-like bodies or spores. After this there is apparently no change for two or three days, and then suddenly the spores becone liberated. They may be quite round, but are usually rather longer in one diameter. I have not observed the develop ment of these spores into fresh filaments, but have no doubt that under suitable conditions this would take place.

Biology. - In plate cultivations growth is slow. In four days we see a small, round, shiny white colony, not raiseci above the surface. Under the microscope it appears dark brown, and later a thick felted arrangement of threads is seen at the periphery. In stroke cultures there is a grey ribbon-like band with smooth edges; very shortly a white, chalky streak appears in the centre of the culture, whicli increases with the development of the organism but always leaves a narrow margin of grey. This chalky portion is at first firmly adherent to the subjacent medium, but about the fifth day it can be removed as a white powder and is founc to consist exclusively of oidia and oidiospores. Liquefaction begins about the same time and advances rapidly. Stab cul. tures are grey, with an irregular and pitted surface, and in the centre there is the same white chalky appearance. Along the puncture there is a good development of numerous closely. arranged but isolated colonies. Agar-agar cultures kept in the incubator at $37^{\circ} \mathrm{C}$. consist of isolated grey plaques, muclr raised at the edges and depressed in the centre. At this temperature no spores are formed, but if kept at the ordinary temperature the white cbalky appearance is quickly developed. In bouillon cultures there are some flaky masses 
at the bottom of the tube, but the fluid remains clear. All cultures have a powerful, musty odour.

\section{General REMARKs.}

Definition.-Several writers seem to have confused Streptothrix and Cladothrix. Thus Macé, in his account of what he calls "Cladothrix dichotoma," describes an undoubted streptothrix. But the distinction is simple enough. Cohn's definitions were:-Cladothrix: very fine leptothrix filaments colourless, not articulated, straight or wavy, with false branching. Streptothrix: very fine leptothrix filaments, colourless, non-articulated, straight or slightly spiral, with true branching. Besides these, they are further distinguished by the former possessing a sheath, which the latter does not. It is, in fact, the presence of a sheath in Cladothrix that accounts for the false branching; for it holds together filaments which without it would fall asunder.

History. - The first to discover the cladothrix was Cohn who two years later described and figured it, together with another organism which von Graefe and afterwards Foerster had observed in the lacrymal canal, and which Cohn now names Streptothrix Foersteri. Cienkowski next studied the cladothrix. In 1877 he stated that he had seen both true and false branching, but as he makes no mention of Streptothrix it is probable that he has confounded the two. Zopf in 1882 published an excellent description of Cladothrix, which was accompanied by several valuable plates; he, however, could not distinguish between the two varieties and says that they could not be separated. But he denies that he has ever seen true branching in any organism whatever, and therefore it is evident that he had never studied the streptothrix. Winter, two years later, considered Streptothrix and Cladothrix as synonymous terms. Macé, in 1888, succeeded in cultivating an organism which he called Cladothrix dichotoma, but, as mentioned before, this was a true streptothrix and differed in several particulars from true Cladothrix dichotoma. The specific cause of cattle disease in Guadeloupe-farcin de bouf--was described in 1889 by Nocard as a cladothrix, but subsequent investigation by Metchnikoff showed it was a streptothrix. Billet, who has considered the cladothrix from every point of view, and has gone into it very exhaustively, has endeavoured to cultivate this organism on ordinary media, but not altogether with success. But in the hanging drop he has observed all the stages of development of the cladothrix, including the formation of rods and coccus forns. Since 1890 Russell cultivated a true cladothrix from sea-water, and Eppinger, from a case of meningitis, has isolated a streptothrix, although he calls it a cladothrix ; other forms of streptothrix have been isolated by Gasperini, Almqvist, Doria, Gruber, Saurageau and Radais, and lastly by myself.

Reproduction. - The methods by which reproduction is provided for in the different species are various. In Cladothrix dichotoma Billet claims to have observed the formation of true endogenous spores. The first stage in their formation is a retraction of the protoplasm of the filaments into a rectangular bacillus-like body, which then divides into two portions, each of which again similarly divides, so that we have the appearance of fine angular or rounded bodies (spores) enclosed within a clear hyaline sheath. In my cladothrix no spores could be observed. Macé says the filaments of Cladothrix dichotoma (sic) may become segmented into'very short rods or spherical bodies, which may be considered as arthrospores. Doria, according to Sauvageau, describes sporiferots filaments which are very much thicker than the vegetative filaments and segment into spores. These swell up by a process but little known, though certainly connected with the presence of air in the interior, and rupture of the investing membrane sets the spores at liberty. The method of sporulation described by Sauvageau and Radais in Oöspora Guignardi is very similar to that of Doria and of my Streptothrix C. The surface of all cultures on solid media is covered with a white powder, which consists of short sporiferous filaments, distinguished from the ordinary vegetative filaments by their much greater thickness. Segmentation takes place simultaneously along the whole filament. The spores are round or oval and can easily be separated from each other. They stain easily with aniline dyes and with Gram's stain. Almqvist describes a very curious method of fructification. When cultivated in a thin layer of fluid the plant gives rise to filaments which rise out of the fluid into the air and there become segmented into oidiospores. These spores become covered with oil produced by the plant itself, so as not to be wetted, and can then be distributed by the wind to other places for derelopment.
Place in classification.-Cohn considered-and his opinion has been closely followed by Zopf and others-that Streptothrix and Cladothrix were closely allied. Sauvageau and Radais, on the other hand, think these two plants have nothing in common. They regard Cladothrix as a bacterium and Streptothrix as a mycelium; the latter, therefore, should be placed amongst the mould fungi and not amongst the bacteria. As regards Streptothrix, Doria believes they belong neither to the bacteria nor to the moulds, but to a special group of their own. Almqvist agrees with Cohn and Brefeld that Streptothrix is a bacterium and forms a connecting link with the Hyphomycetes. I rather incline towards Sauvageau's view that Streptothrix and Cladothrix are not at all closely allied. The latter, I think there can be no doubt, belongs to the group of Bacteria; but the proper place for Streptothrix is by no means so readily determined. In certain characters-for example, the appearance of so-called coccus forms and short rods-they resemble the bacteria other characters, however, such as the musty odour which most of them possess, and especially their fructification by means of conidia, point very conclusively to the Hyphomycetes. They undoubtedly form a connecting link between the two families, but, I think, should be placed rather among the latter than the former.

Bibliography.-Almqvist: Untersuchungen über einige Bacteriengattungen mit Mycelien (Zeitschrift für Hygiene, 1890). Billet : Contribution à l'Etude de la Morphologie et du Développement des Bactériacées (Paris, 1890). Cienkowski : Zur Morphologie der Bacterien (Mémoire de l'Académie. Impériale des Sciences de St.-Pétersbourg, 1877). Doria Su di alcune Specie di Streptothrix trovate nell' Aria (Annali dell' Istituto d'Igiene di Roma, 1891). Eppinger : Ueber eine neue pathogene Cladothrix (Beiträge zur Pathologischen. Anatomie, 1890). Gasperini : Recherches Morphologiques et Biologiques sur un Micro-organisme de l'Air (Annales. de Micrographie, 1890); Sopra una nuova Specie appartenente al Genere Streptothrix (Pise, 1891). Macé Sur les Caractères des Cultures de Cladothrix dichotoma (Comptes-rendus de l'Académie des Sciences, 1888); Traité Pratique de Bactériologie (Paris, 1892). Nocard: Sur le Farcin de Bœuf (Annales de l'Institut Pasteur, 1888).। Russell: Ueber im Golf von Neapel lebende Bacterien (Zeitschrift für Hygiene, Band xi.). Winter: Die Pilze (1884). Zopf : Die Spaltpilze (1885).

\section{de attirtor \\ OF}

\section{HOSPITAL PRACTICE, BRITISH AND FOREIGN.}

Nulla autem est alia pro certo noscendi via, nisi quamplurimas et morborum et dissectionum historias, tum aliorum tum proprias collectas habere, et inter se comparare.-Morgagni De Sed. et Caus. Morb., lib. iv. Procemium

\section{ROYAL FREE HOSPITAL.}

PNEUMONIA FOLLOWED BY ULCERATIVE ENDOCARDITIS AND MENINGITIS.

(Under the care of Dr. SaInsBuRy.)

CASES of malignant endocarditis, though not very infrequent, are always interesting, and in particular in their etiology. The present case illustrates the well-known but illunderstood relation between pneumonia and this form of endocarditis. According to Osler pneumonia was present in 11 out of 23 cases observed in Montreal and in 54 out of the 209 cases which he analysed in his Gulstonian Lecture. Meningitis is a not infrequent further complication ; it was observed in 25 of the 209 cases, and in 15 of these 25 there was also pneumonia. For the notes of this case we are in debted to Mr. Wilmot H. Evans, B.Sc. Lond., registrar.

A furniture porter was admitted into the Royal Free Hos pital on Nov. 11th, 1892, under the care of Dr. Sainsbury, complaining of pain in the side and shortness of breath. Ir his family history there was nothing noteworthy. $\mathrm{He}$ hac lived in London for the greater part of his life, well clothe 